\title{
Thermal requirements of Trissolcus grandis (Hymenoptera: Scelionidae), an egg parasitoid of sunn pest
}

\author{
SHAHZAD IRANIPOUR ${ }^{1}$, ZAHRA NOZAD BONAB ${ }^{1}$ and JOHN P. MICHAUD ${ }^{2}$ \\ ${ }^{1}$ Department of Plant Protection, Faculty of Agriculture, University of Tabriz, 51666-14888 Tabriz, Iran; \\ e-mail: shiranipour@tabrizu.ac.ir \\ ${ }^{2}$ Department of Entomology, Kansas State University, Agricultural Research Center-Hays, 1232 240th Ave, Hays, KS 67601, USA; \\ e-mail:.jpmi@ksu.edu
}

Key words. Hymenoptera, Scelionidae, Trissolcus grandis, egg parasitoid, Hemiptera, Scutelleridae, Eurygaster integriceps, degree-day, development, sunn pest, fecundity, longevity, thermal constant, thermal threshold

\begin{abstract}
Trissolcus grandis is an important egg parasitoid of sunn pest, Eurygaster integriceps Puton (Hemiptera: Scutelleridae), the most serious pest of wheat in Iran. The thermal requirements of two populations of $T$. grandis were studied at five constant temperatures ranging from $20-32^{\circ} \mathrm{C}$. Thermal thresholds for development were calculated using linear regression and degree-day models were determined by fitting non-linear equations to the data. The lower threshold for development was estimated to be 12.5 and $12.1^{\circ} \mathrm{C}$, respectively, for males and females of the Bonab population, compared to 14.4 and $14.5^{\circ} \mathrm{C}$ for those of the Qaramalek population. Complete development required 143.8 and 162.8 degree-days, respectively, for males and females of the Bonab population and 116.9 and 124.6 for those of the Qaramalek population. Thus, wasps from the warmer region (Qaramalek) developed faster than those from the cooler region (Bonab), but had a higher thermal threshold for initiating development. Bonab females attained their highest fecundity $(117.7 \pm 7.2)$ at the lowest temperature tested $\left(20^{\circ} \mathrm{C}\right)$, whereas the fecundity of Qaramalek females was maximal $(96.8 \pm 11.5)$ at $26^{\circ} \mathrm{C}$. Biological control programmes that seek to augment wasp populations in wheat fields early in the spring, when natural rates of sunn pest parasitism tend to be low, should consider wasp thermal requirements to ensure the selection and release of locally-adapted parasitoids.
\end{abstract}

\section{INTRODUCTION}

Cereal bugs belonging to Eurygaster, Aelia, Odontotarsus, Dolycoris and several other genera are well known pests of wheat and barley in Middle Eastern countries (Safavi, 1973; Salavatiyan, 1991; Radjabi, 2000). The common sunn pest, Eurygaster integriceps Puton, is perhaps the most injurious and is of high economic importance in Iran. The sunn pest problem is more serious in hot central parts of Iran than in colder regions like Azerbaijan or in adjacent countries like Turkey (Alexandrov, 1947; Davatchi; 1954; Safavi, 1973; Salavatian, 1991; Radjabii, 2000, 2007). Radjabi (2000, 2007) concluded that temperature is the best indicator for explaining differences observed among locations. Several scelionid wasp species, primarily Trissolcus grandis Thomson, parasitize sunn pest eggs in Iran (Martin et al., 1969; Radjabi \& Amir Nazari, 1989; Iranipour, 1996; Amir Maafi, 2000). The rate of parasitism has also been reported to range from $<10 \%$ in cold regions (Haghshenas, 2004; Nozad \& Iranipour, 2009) to as much as $100 \%$ in warm regions such as Syria (El-Bouhsinni et al., 2004). Thus, a great deal of variation exists in both pest injury and parasitoid efficiency across the geographic range of these species that likely reflects variation in their biological performance under local conditions, especially their responses to temperature.

Differences in thermal thresholds and constants may lead to asynchronies between the host and parasitoid under field conditions. Thus, the thermal requirements of a parasitoid, particularly in relation to its host, may assist us in forecasting outbreaks and the need for chemical treatments to avert crop losses. Linear models have been widely used to simulate biological relationships with temperature (Varley et al., 1973; Shojai, 1996; Dent, 1997), but the typical effect of temperature on insect developmental rate follows a sigmoid pattern (Andrewartha \& Birch, 1954; Dent, 1997; Radjabi, 2008). Development begins at a critical thermal threshold, development rate gradually increases to an inflection point, and then approaches an asymptote with an instantaneously decreasing slope. The rate of change is low near the extreme temperatures (both lower and upper thresholds) and much steeper at intermediate temperatures.

The relationship between temperature and development has been studied in a number of scelionid species (Orr et al., 1985; Ruberson et al., 1995; Canto-Silva et al., 2005; Sadoyama, 2007; Austin, 2008; Bueno et al., 2008) and data is also available on the host species (Iranipour et al., 2003; Kivan, 2008), as well as some Trissolcus species (Yeargan, 1983; James \& Warren, 1991; Torres et al., 1997, 2002; Cividanes et al., 1998; Arakawa \& Namura, 2002; Kivan \& Kiliç, 2006a, b). There is also similar information available on $T$. grandis populations originating from central parts of the Iranian plateau (Safavi, 1973; Amir Maafi, 2000) but no published information on populations from colder regions. This study was conducted to examine the effect of temperature on the devel- 
opment, fecundity and longevity of two $T$. grandis populations originating from East-Azerbaijan province, a region in northwest Iran.

\section{MATERIAL AND METHODS}

\section{Source of insects}

One population of $T$. grandis used in this study was obtained from Qaramalek, to the west of Tabriz (longitude $46^{\circ} 13^{\prime} \mathrm{E}$, latitude $38^{\circ} 6^{\prime} \mathrm{N}$ ), and the other from New Bonab county, $11 \mathrm{~km}$ east of Marand (longitude $45^{\circ} 55^{\prime} \mathrm{E}$, latitude $38^{\circ} 26^{\prime} \mathrm{N}$ ). The two localities were $\approx 50 \mathrm{~km}$ distance from each other. The wasps were collected as parasitized host eggs and identified after emergence using an identification key (Kozlov \& Kononova, 1983). A second generation of wasps was reared for use in experiments.

Adult bugs of E. integriceps were collected, as needed, from Bonab county to provide host eggs for the parasitoid during study.

\section{Insect rearing}

A stock colony of $E$. integriceps was maintained on wheat kernels in rectangular plastic containers $(20 \times 14 \times 6 \mathrm{~cm})$ in the laboratory in $25 \pm 2{ }^{\circ} \mathrm{C}, 40 \pm 10 \% \mathrm{RH}$ and $16 \mathrm{~L}: 8 \mathrm{D}$ photoperiod as described by Zomorrodi (1961). All eggs were removed daily. Wasps emerging from field-collected, parasitized eggs were allowed to mate in $10 \mathrm{~cm}^{3}$ glass vials and were fed honey droplets before exposure to host eggs. Parasitized eggs were maintained under the same conditions as above until emergence of the $F_{2}$ adults that were used in experiments.

\section{Experimental design}

For each parasitoid population, 200 host eggs $(<24 \mathrm{~h}$ old $)$ were exposed to one day old adult females of the $2^{\text {nd }}$ generation for $24 \mathrm{~h}$, whereupon parasitized eggs of each population were divided to five groups and each placed in a growth chamber calibrated to $20,23,26,29$, and $32 \pm 1{ }^{\circ} \mathrm{C}$, respectively. Conditions of $50 \pm 5 \% \mathrm{RH}$ and $16 \mathrm{~L}: 8 \mathrm{D}$ photoperiod were maintained in all treatments. These temperatures were selected based on a preliminary experiment performed to estimate an acceptable range of temperatures for the wasp. After emergence, each female was paired with a male for $24 \mathrm{~h}$ in a $10 \mathrm{~cm}^{3}$ glass vial sealed with a plastic plug bearing a $3 \times 3 \mathrm{~mm}$ hole covered by 50 mesh fabric, after which the male was removed and held separately. The female remained isolated in the vial for the duration of her life and was fed honey droplets daily. Fresh host eggs ( $<24 \mathrm{~h}$ old $)$ were offered daily to females: 50, 40, 30, 20 and 10 eggs/female on the first, second, third, fourth and remaining days of adult life. These values were selected to ensure females had an excess of hosts available and were derived from a preliminary experiment designed to measure female ovipositional capacity as a function of age.

The following data were recorded: developmental time (number of days from oviposition until adult emergence), preoviposition period (number of days from emergence to first oviposition), oviposition period (number of days from first to last oviposition), post-oviposition period (number of days from last oviposition until death), adult longevity (number of days from adult emergence until death), and life time fecundity (total number of progeny emerging). Data for females that produced no offspring were excluded from analysis of adult life history parameters.

\section{Data analysis}

A linear regression of developmental rate on temperature was used for estimating the thermal requirements of $T$. grandis, where the reciprocal of the line slope is the thermal constant and the $\mathrm{x}$-intercept equals the lower thermal threshold for development (Campbell et al., 1974; Bernal \& Gonzalez, 1993). Parameter estimation and the regression ANOVA were carried out in an Excel spreadsheet (Microsoft Corporation, Redmond, Washington). Data also were fitted to a logistic model:

$$
y=\frac{K}{1+\left(e^{a+b x}\right)}
$$

in which $y$ is developmental rate, $e$ is the base of natural logarithms, and $K, a$, and $b$ are the estimated parameters of the model (Radjabi, 2008). The predictions of the two models were then compared.

In order to compare life history parameters among treatments, a factorial 3-way ANOVA was performed with "temperature", "population" and "gender" as independent variables in an unbalanced, completely randomized design using the General Linear Model procedure of SAS (SAS Institute, 1999). Gender was disregarded in analysis of female-specific variables. One-way ANOVA was used to compare population parameters at each temperature and linear regression was used to analyze the relationships between fecundity and longevity and between fecundity and oviposition period.

\section{RESULTS}

\section{Developmental time}

Males developed significantly faster than females $(\mathrm{F}=$ 77.67; df $=1,277 ; \mathrm{P}<0.0001)$, there were significant effects of temperature $(\mathrm{F}=2001.27$; $\mathrm{df}=4,277 ; \mathrm{P}<$ $0.0001)$ and population $(\mathrm{F}=4.83 ; \mathrm{df}=1,277 ; \mathrm{P}=0.029)$ on developmental time, and significant interactions "gender*temperature" ( $\mathrm{F}=2.94, \mathrm{df}=4,277 ; \mathrm{P}=0.021)$ and "temperature*population" $(\mathrm{F}=4.04 ; \mathrm{df}=4,277 ; \mathrm{P}=$ $0.0033)$. Neither the "gender*population" $(\mathrm{F}=0.19$; $\mathrm{df}=$ $1,277 ; \mathrm{P}=0.66)$ nor the three-way interaction $(\mathrm{F}=0.20$; $\mathrm{df}=4,277$; $\mathrm{P}=0.94)$ were significant. Qaramalek males developed significantly faster than Bonab males at the highest temperature (Table 1), and Qaramalek females faster than Bonab females at the two highest temperatures (Table 2).

\section{Preoviposition period}

Since most females laid eggs immediately upon being provisioned with hosts, a pre-oviposition period was not observed except for five females of the Bonab population in the 20 and $32^{\circ} \mathrm{C}$ treatments. In these cases, females delayed oviposition by one or two days post-emergence, and in one case, 11 days. Consequently, no analysis of pre-oviposition period was performed.

\section{Oviposition period}

Oviposition period was affected by both temperature (F $=21.63 ; \mathrm{df}=4,146 ; \mathrm{P}<0.0001)$ and population $(\mathrm{F}=$ $11.61 ; \mathrm{df}=1,146 ; \mathrm{P}=0.0008)$ and the interaction between these two factors was also significant $(\mathrm{F}=3.61$; $\mathrm{df}=4,146 ; \mathrm{P}=0.0077)$. The oviposition period tended to decrease with increasing temperature, beginning at $20^{\circ} \mathrm{C}$ in the Bonab population, but not until temperatures exceeded $23^{\circ} \mathrm{C}$ in the Qaramalek population (Table 2). The oviposition period of Bonab females tended to be longer than that of Qaramalek females and the difference was significant at both $20^{\circ} \mathrm{C}$ and $29^{\circ} \mathrm{C}$ (Table 2). 
TABLE 1. Mean ( \pm SE) life history parameters of male Trissolcus grandis from two populations reared at five constant temperatures. Asterisks indicate values that were significantly different between populations (one-way ANOVA) at a particular temperature $(*-\alpha \leq 0.05 ; * *-\alpha \leq 0.01 ; * *-\alpha \leq 0.001)$.

\begin{tabular}{lccc}
\hline Population & Temperature $\left({ }^{\circ} \mathrm{C}\right)$ & Developmental time $(\mathrm{d})$ & Adult longevity $(\mathrm{d})$ \\
\hline \multirow{3}{*}{ Qaramalek } & 20 & $20.4( \pm 0.4)$ & $30.3( \pm 9.1)$ \\
& 23 & $15.5( \pm 0.2)$ & $28.9( \pm 3.9)$ \\
& 26 & $9.1( \pm 0.1)$ & $18.9( \pm 1.9)$ \\
& 29 & $7.8( \pm 0.1)$ & $19.6( \pm 2.1)$ \\
Bonab & 32 & $6.9( \pm 0.1)^{* * *}$ & $12.4( \pm 1.1)^{* * *}$ \\
\hline 20 & $20.2( \pm 0.6)$ & $39.6( \pm 4.2)$ \\
& 23 & $15.5( \pm 0.2)$ & $33.2( \pm 3.3)$ \\
& 29 & $9.3( \pm 0.1)$ & $16.5( \pm 1.7)$ \\
& 32 & $8.0( \pm 0.0)$ & $17.0( \pm 2.0)$ \\
\end{tabular}

\section{Longevity}

Adult longevity decreased with increasing temperature $(\mathrm{F}=81.50 ; \mathrm{df}=4,235 ; \mathrm{P}<0.0001)$ and females lived longer than males by an average of three days $(\mathrm{F}=9.36$; $\mathrm{df}=1,235 ; \mathrm{P}=0.0025)$, but there was no significant effect of population $(\mathrm{F}=0.01 ; \mathrm{df}=1,235 ; \mathrm{P}=0.911)$. There was a significant "temperature*population" interaction $(\mathrm{F}=3.29 ; \mathrm{df}=4,235 ; \mathrm{P}=0.012)$, but the "gender*population" interaction was not significant $(\mathrm{F}=$ $0.17 ; \mathrm{df}=1,235 ; \mathrm{P}=0.684)$. The regression of temperature on longevity produced a steeper line slope for Bonab males than Qaramalek males $\left(\mathrm{b}_{\mathrm{Bonab}}=-2.796 ; \mathrm{r}^{2}=0.639\right.$ vs. $\left.b_{\text {Qaramalek }}=-1.531 ; \mathrm{r}^{2}=0.397\right)$, but due to substantial variation, the only significant within-treatment difference occurred at the highest temperature: Bonab males had significantly shorter lives at that temperature (Table 1). The same pattern was evident in females, with Bonab females exhibiting steeper line slopes $\left(b_{\text {bonab }}=-2.708 ; r^{2}=0.683\right.$ vs. $\left.b_{\text {qaramalek }}=-2.240 ; r^{2}=0.679\right)$ and shorter lives at the highest temperature (Table 2). Females lived anywhere from 5 to 25 days after ceasing oviposition, depending on treatment, and this was a large contributor to variation in longevity. However, since post-reproductive longevity makes no contribution to fitness and may be largely an artifact of laboratory confinement, it was not considered separately from longevity.

\section{Lifetime fecundity}

Temperature had a significant effect on lifetime fecundity $(\mathrm{F}=5.15 ; \mathrm{df}=4,146 ; \mathrm{P}=0.0007)$. There was no significant effect of population on fecundity $(\mathrm{F}=0.07$; $\mathrm{df}$ $=1,146 ; \mathrm{P}=0.797)$, but the "temperature*population" interaction was significant $(\mathrm{F}=3.04$; $\mathrm{df}=4,146 ; \mathrm{P}=$ $0.019)$. Fecundity in both populations was lowest at the highest temperature tested $\left(32^{\circ} \mathrm{C}\right)$. Fecundity in the Bonab population was highest at the lowest temperature tested, suggesting that the thermal optimum for reproduction might be even lower than $20^{\circ} \mathrm{C}$ in this population. In contrast, Qaramalek females had maximum fecundity at $26^{\circ} \mathrm{C}$ and significantly lower fecundity than Bonab females at $20^{\circ} \mathrm{C}$. There was a significant correlation between fecundity and female longevity $(\mathrm{F}=22.60$; $\mathrm{df}=$ 1,$\left.154 ; \mathrm{P}<0.001 ; \mathrm{r}^{2}=0.128\right)$, and between fecundity and oviposition period $\left(\mathrm{F}=101.77 ; \mathrm{df}=1,154 ; \mathrm{P}<0.001 ; \mathrm{r}^{2}\right.$ $=0.398)$.

\section{Linear regressions}

Thermal thresholds for development in the Qaramalek population were higher $\left(14.4\right.$ and $14.5^{\circ} \mathrm{C}$ for males and females, respectively) than those of the Bonab population (12.5 and $12.1^{\circ} \mathrm{C}$, respectively). The Bonab population also required more cumulative degree-days (DD) to complete development (143.8 and 162.8 DD for males and females, respectively) than did the Qaramalek population

TABLE 2. Mean ( \pm SE) life history parameters of female Trissolcus grandis from two populations reared at five constant temperatures. Asterisks indicate values that were significantly different between populations (one-way ANOVA) at a particular temperature $(*-\alpha \leq 0.05 ; * *-\alpha \leq 0.01 ; * * *-\alpha \leq 0.001)$.

\begin{tabular}{lccccc}
\hline Population & Temperature $\left({ }^{\circ} \mathrm{C}\right)$ & Development time $(\mathrm{d})$ & Oviposition period $(\mathrm{d})$ & Adult longevity $(\mathrm{d})$ & Fecundity \\
\hline \multirow{4}{*}{ Qaramalek } & 20 & $22.2( \pm 0.4)$ & $11.8( \pm 2.3)^{* *}$ & $41.8( \pm 1.5)$ & $70.6( \pm 10.7)^{* *}$ \\
& 23 & $16.5( \pm 0.2)$ & $14.2( \pm 2.5)$ & $29.8( \pm 2.9)$ & $89.7( \pm 15.8)$ \\
& 26 & $9.8( \pm 0.2)$ & $8.0( \pm 1.1)$ & $22.3( \pm 1.6)$ & $96.8( \pm 11.5)$ \\
& 29 & $8.7( \pm 0.1)^{*}$ & $6.0( \pm 0.8)^{*}$ & $21.6( \pm 1.9)$ & $90.3( \pm 12.5)$ \\
Bonab & 32 & $7.3( \pm 0.2)^{* * *}$ & $4.8( \pm 0.8)$ & $13.3( \pm 0.7)^{* * *}$ & $56.5( \pm 7.9)$ \\
\hline & 20 & $21.9( \pm 0.7)$ & $22.4( \pm 2.3)^{* *}$ & $41.7( \pm 2.1)$ & $117.7( \pm 7.2)^{* *}$ \\
& 23 & $16.4( \pm 0.2)$ & $14.6( \pm 2.5)$ & $34.2( \pm 3.6)$ & $84.9( \pm 13.3)$ \\
& 26 & $10.2( \pm 0.1)$ & $10.7( \pm 1.1)$ & $23.6( \pm 1.5)$ & $85.8( \pm 13.0)$ \\
& 32 & $9.0( \pm 0.0)^{*}$ & $9.3( \pm 0.9)^{*}$ & $18.5( \pm 1.7)$ & $67.2( \pm 7.5)$ \\
\hline
\end{tabular}




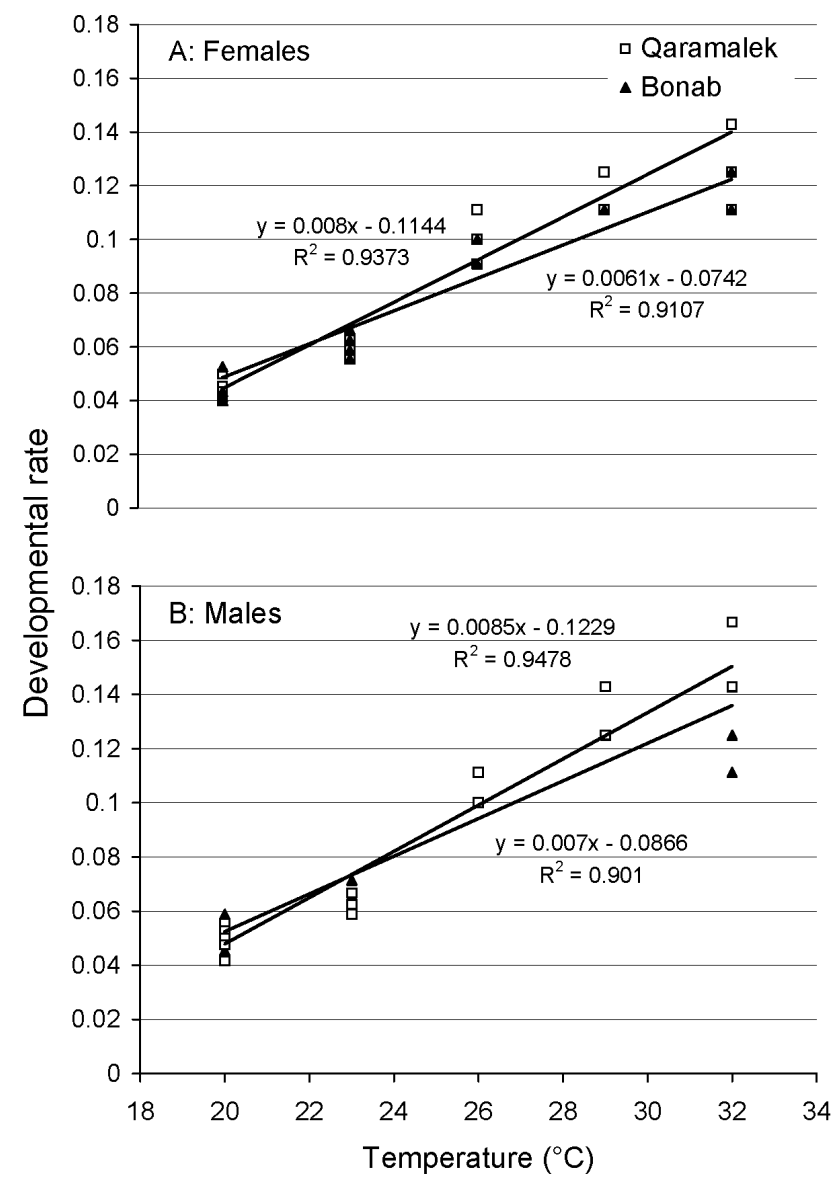

Fig. 1. Linear regressions of developmental rate for two populations of Trissolcus grandis based on data obtained at five constant temperatures.
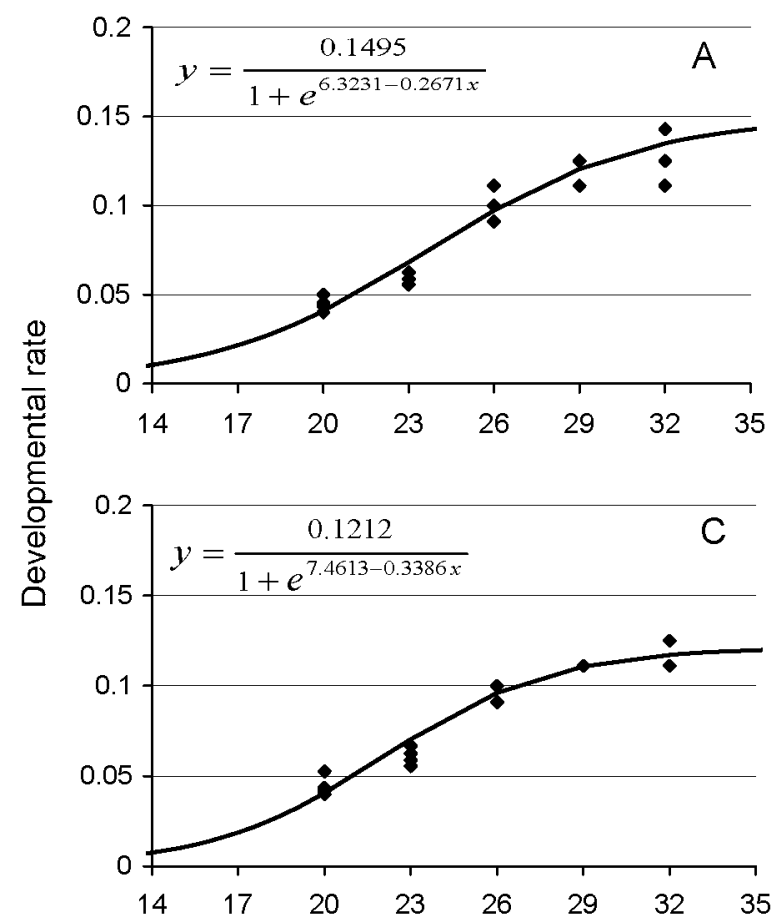

Temperature $\left({ }^{\circ} \mathrm{C}\right)$

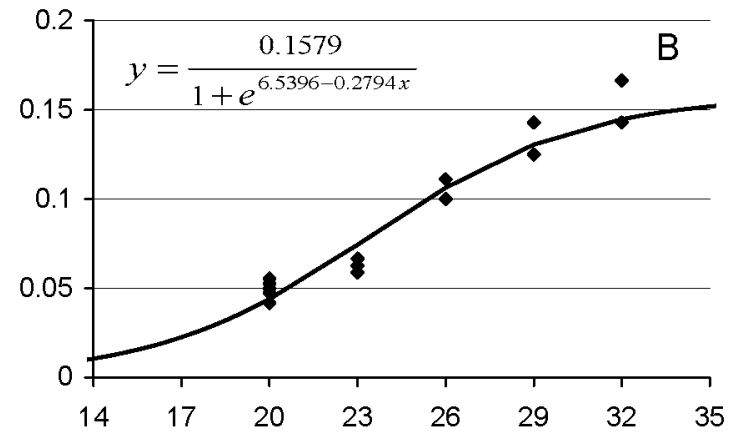

(116.9 and 124.6 DD, respectively). Linear regressions of developmental rate on temperature were significant for Bonab males $\left(\mathrm{F}=600.81 ; \mathrm{df}=1,66 ; \mathrm{r}^{2}=0.901 ; \mathrm{P}<\right.$ $0.0001)$, Bonab females $\left(\mathrm{F}=907.47\right.$; $\mathrm{df}=1,89 ; \mathrm{r}^{2}=$ 0.911; $\mathrm{P}<0.0001)$, Qaramalek males $(\mathrm{F}=1161.53$; $\mathrm{df}=$ 1,$\left.64 ; \mathrm{r}^{2}=0.948 ; \mathrm{P}<0.0001\right)$ and Qaramalek females $(\mathrm{F}$ $\left.=1047.26 ; \mathrm{df}=1,70 ; \mathrm{r}^{2}=0.937 ; \mathrm{P}<0.0001\right)$. There were also significant differences between the slopes of the regression lines for the two populations (males: $t=24.53$; df $=130 ; \mathrm{P}<0.001$; females: $\mathrm{t}=34.77$; $\mathrm{df}=159 ; \mathrm{P}<$ 0.001 ; Fig. 1). These lines intersected at 22.9 and $22.3^{\circ} \mathrm{C}$ in males and females, respectively, indicating that developmental rates of the two populations were equivalent at those temperatures. Consequently, the development of Bonab wasps was faster than Qaramalek below these temperatures, and slower above them. There were also differences in the slopes of regression lines for males and females within each population (Bonab: $\mathrm{t}=14.18$; $\mathrm{df}=$ 155; $\mathrm{P}<0.001$ and Qaramalek: $\mathrm{t}=10.15$; $\mathrm{df}=134 ; \mathrm{P}<$ $0.001)$.

\section{Logistic regressions}

The logistic model also provided a good fit to the data (Fig. 2). In all cases, coefficients of determination were slightly greater for the logistic model than for the linear model. Predictions of the two models overlapped to such a large degree over the range of temperatures studied that no more than a $10 \%$ difference was ever evident between them. However, beyond this range, differences increased. The estimated parameters of the model for Bonab wasps were: $\mathrm{a}_{\delta}=7.4958 ; \mathrm{b}=-0.3374 ; \mathrm{K}=0.1356$ and $\mathrm{a}_{\circ}=$ $7.4613 ; \mathrm{b}=-0.3386 ; \mathrm{K}=0.1212$ and for Qaramalek

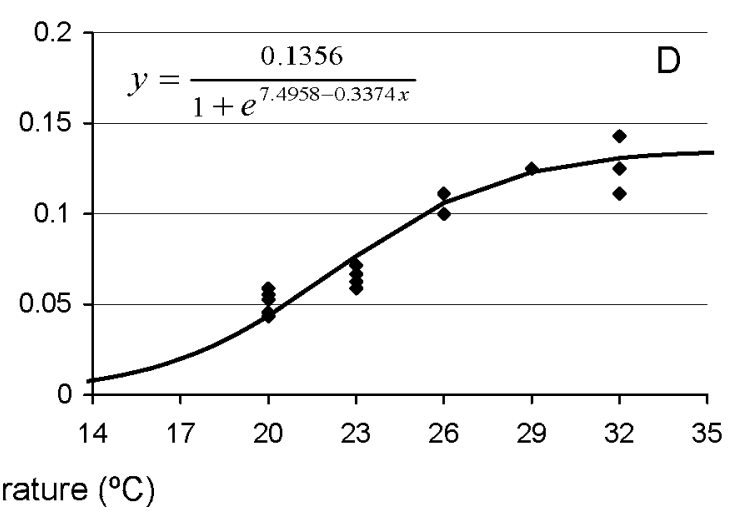

Fig. 2. Temperature-dependent developmental rates of the two populations of Trissolcus grandis predicted by logistic models based on data obtained at five constant temperatures. A - Qaramalek females; B - Qaramalek males; C - Bonab females; D - Bonab males. 
wasps: $\mathrm{a}_{\delta}=6.5396 ; \mathrm{b}=-0.2794 ; \mathrm{K}=0.1579$ and $\mathrm{a}_{\uparrow}=$ $6.3231 ; b=-0.2671 ; \mathrm{K}=0.1495$.

\section{DISCUSSION}

The thermal threshold of the Bonab population was $2^{\circ} \mathrm{C}$ lower than that of the Qaramalek population, suggesting that Bonab wasps are able to begin their activity earlier in spring in a cool climate. On the other hand, the thermal requirements were 27-38 degree-days higher than those of Qaramalek wasps due to the lower slope of the regression line of development against temperature, indicating that the Bonab population required more thermal energy to complete development. These differences correspond well to climatic differences between the two locations. The nearest meteorological stations to Qaramalek and Bonab were the Tabriz International Airport and the Marand Station, respectively, and both were $\approx 10 \mathrm{~km}$ distant from the fields where parasitoids were collected without any significant difference in elevation. Meteorological data of the last eight years from these stations reveals that Marand is on average $0.8^{\circ} \mathrm{C}$ colder than Tabriz, a disparity that rises to $3^{\circ} \mathrm{C}$ during the hottest hours of the day. Clearly, the colder conditions that persist in Bonab have selected for wasps that are able to begin their activity with fewer accumulated DD. Males of both populations developed faster than females and died earlier. Protandry is adaptive for egg parasitoids such as $T$. grandis because it ensures that females mate immediately upon emergence and prior to dispersal (Godfray, 1994).

Developmental rate, oviposition period and longevity all declined with increasing temperature in both populations. Fecundity was lowest at $32^{\circ} \mathrm{C}$ in both populations, suggesting that this temperature is beyond the optimal range for this species. However, fecundity was maximal at $20^{\circ} \mathrm{C}$ for Bonab females, compared to $26^{\circ} \mathrm{C}$ for Qaramalek females, further supporting the inference of superior adaptation to warmer conditions in this population.

Developmental rate tends to increase more slowly with temperature in populations from colder regions and higher latitudes. Honěk (1996) reviewed data on 335 insect species in different latitudes and noticed that insects originating from higher latitudes had lower thermal thresholds, but required more degree-days to complete a specified amount of development, in comparison to those from lower latitudes. The taxa reviewed included scelionid species such as Trissolcus basalis (Wollaston), T. oenone (Dodd), Telenomus chloropus Thomson, and Telenomus podisi Ashmead. Although insects from cold climates are able to begin development early while the weather is still cold, they require more time to complete development despite experiencing a shorter season. Thus, there may exist a trade-off between the speed of development at warm temperatures and how early in the season development can begin. This trade-off is likely mediated by the thermal properties of enzymes that govern critical developmental processes; allozymes with lower activation temperatures may also have lower maximal rates of substrate turnover at higher temperatures, leading to slower development (Ratte, 1985). This inference is also consistent with Qaramalek wasps completing development more quickly than Bonab wasps at the highest temperatures. The ecological implication is that insect fitness is improved more by early onset of development in cool climates than it is by faster development, whereas the reverse is true in warmer climates.

In contrast, Kipyatkov et al. (2004) studying Lasius niger (L.) workers found that thermal requirements of northern populations of this ant were lower, and their developmental threshold higher, than southern ones. However, northern populations diapause in winter and begin activity late in spring when the risk of a freeze has passed. Upon termination of diapause, individuals undergo accelerated development to compensate for the delay. This may explain the differences between the results of our study and those of Kipyatkov et al. (2004). Honěk \& Kocourek (1990) reviewed 294 species belonging to nine insect orders and found that, on average, there is an increase of 10 DD in the thermal constant of eggs and pupae for every 0.31 and $0.19^{\circ} \mathrm{C}$ decrease in thermal threshold, respectively. This is consistent with our finding that Bonab wasps required more DD to complete development despite having a lower thermal threshold than Qaramalek wasps.

Developmental times obtained for the two wasp populations in this study are comparable to values obtained by Safavi (1973) and Amir Maafi (2000). The results of Safavi (1973) can be fitted to a linear model with a thermal threshold of $13.82^{\circ} \mathrm{C}$ and a constant of 126.58 DD, values close to those of the Qaramalek population. On the other hand, Amir Maafi (2000) estimated logistic parameters for males and females based on seven temperatures ranging from 16 to $35^{\circ} \mathrm{C}$. The absolute values of both "a" and "b" that he obtained were smaller than those of our populations, but the asymptote " $\mathrm{K}$ " was well within the range of our results. The observed differences are probably attributable to the different origin of our populations. Excluding values obtained at $35^{\circ} \mathrm{C}$ in his study (at which developmental rate decreased), his data yield thermal constants of 136.24 and 164.39 DD above thresholds of 12.39 and $12.24^{\circ} \mathrm{C}$ for males and females, respectively, values comparable to those of the Bonab population in this study. In contrast, the fecundity reported by Amir Maafi (2000) was more than twice that of our populations. These intrinsic differences may partly explain differences in observed rates of parasitism by the two populations under field conditions. Values reported by Taghaddosi et al. (1993), and Asgari \& Kharrazi Pakdel (1998) who worked on the same population or one in close proximity, were intermediate.

The thermal requirements of a parasitoid require ecological interpretation within the context of those of its host. Eurygaster integriceps has a relatively short life cycle that is closely synchronized with the availability of its host plant, wheat. Thus, in all regions, T. grandis has only a narrow window of opportunity to attack host egg masses in suitable stages of development, and this requires close synchronization of its development with that of its host. Iranipour et al. (2003) and Kivan (2008) 
determined the thermal requirements of E. integriceps in separate studies that examined different populations. Iranipour et al. (2003) studied the host from Varamin at the margins of the central desert of Iran and obtained 38.83 and $275.26 \mathrm{DD}$ above a threshold of $18.85^{\circ} \mathrm{C}$ for egg and preimaginal development, respectively. In contrast, Kivan (2008) studied E. integriceps collected from Tekirdag, Turkey, on the Aegean coast and obtained a 90.9 DD constant for egg development above a threshold of $11.7^{\circ} \mathrm{C}$. This large difference likely reflects differences in thermal adaptation between the two populations in question, the former originating from a much hotter region. In general, the incubation period of E. integriceps eggs is shorter than the developmental period of the parasitoid at a specified temperature. Iranipour (1996) observed that $T$. grandis was often active in wheat fields in Karaj, Iran, prior to the appearance of its host, but early-season parasitism is usually low (Radjabi, 2000; Iranipour, 2003), probably due to low densities of overwintered females. Thus, efforts at conservation of the parasitoid, along with possible augmentative releases early in the season (taking into account the faster development of host eggs), may be appropriate components of an integrated pest management strategy for sunn pest. Given the present results, it is clear that care should be taken to match parasitoid source material for laboratory colonies to regions of intended release if a rear-and-release programme is to be undertaken, and to select appropriate temperature regimes for rearing particular parasitoid populations.

ACKNOWLEDGEMENTS. This study was financially supported, and facilities provided by, the University of Tabriz. We are thankful to G. and Z. Nozad, S. Nanpaz, and R. Karimzadeh for assistance.

\section{REFERENCES}

AleXandrov N. 1947: Eurygaster integriceps Put. a Varamine et ses parasites. Entomol. Phytopath. Appl. 5: 29-41 [in Persian, French abstr.].

Amir Maffi M. 2000: An Investigation on the Host-Parasitoid System between Trissolcus grandis Thomson (Hym.: Scelionidae) and Sunn Pest Eggs. Ph.D. thesis, Faculty of Agriculture, University of Tehran, Karaj, Iran, 220 pp. [in Persian, English abstr.].

Andrewartha H.G. \& BIRCH L.C. 1954: The Distribution and Abundance of Animals. University of Chicago Press, Chicago, $782 \mathrm{pp}$.

ARAKAWA R. \& NAMURA Y. 2002: Effects of temperature on development of three Trissolcus spp. (Hymenoptera: Scelionidae), egg parasitoids of the brown marmorated stink bug, Halyomorpha halys (Hemiptera: Pentatomidae). Entomol. Sci. 5: 215-218.

Asgari S. \& Kharrazi Pakdel A. 1998: Evaluation of some biological parameters affecting sunn pest egg parasitoid, Trissolcus grandis (Thom.) (Hym., Scelionidae). Proceedings of the 13th Iranian Plant Protection Congress, 23-27 August 1998, Karaj, Iran. Vol. 1. Karaj, p. 28.

Austin A.D. 2008: The fecundity, development and host relationships of Ceratobaeus spp. (Hymenoptera: Scelionidae), parasites of spider eggs. Ecol. Entomol. 9: 125-138.

Bernal J. \& Gonzalez D. 1993: Experimental assessment of degree-day model for predicting the development of parasites in the field. J. Appl. Entomol. 116: 456-466.
Bueno R.C.O., Carneiro T.R., Pratissoli D., Bueno A.D.F. \& FERNANDES A. 2008: Biology and thermal requirements of Telenomus remus reared on fall armyworm Spodoptera frugiperda eggs. Ciência Rural 33: 1-6.

Campbell A., Frazer B.D., Gilbert N., Gutierrez A.P. \& Mackauer M. 1974: Temperature requirements of some aphids and their parasites. J. Appl. Ecol. 11: 431-438.

Canto-Silva C.R., Romanowski H.P. \& Redaelli L.R. 2005: Effect of temperature on the development and viability of Gryon gallardoi (Brethes) (Hymenoptera: Scelionidae) parasitizing Spartocera dentiventris (Berg) (Hemiptera: Coreidae) eggs. Braz. J. Biol. 65(3): 78-83.

Cividanes F.J., Figueiredo J.G. \& Carvalho D.R. 1998: Prediction of the emergence of Trissolcus brochymenae (Ashmead) and Telenomus podisi Ashmead (Hym: Scelionidae) in the field. Sciencia Agricola 55: 43-47.

Davatchi A. 1954: Insect Pests of Iran, Grasshoppers and Other Cereal Insect Pests. Tehran University Press, Teheran, 245 pp. [in Persian].

DENT D.R. 1997: Quantifying insect populations: estimates and parameters. In Dent D.R. \& Walton M.P. (eds): Methods in Ecological and Agricultural Entomology. CAB International, Wallingford, pp. 57-109.

El Bouhssini M., Abdulhai M. \& Bobi A. 2004: Sunn pest (Hemiptera: Scutelleridae) oviposition and egg parasitism in Syria. Pak. J. Biol. Sci. 7: 934-936.

Godfray H.C.J. 1994: Parasitoids: Behavioral and Evolutionary Ecology. Princeton University Press, Princeton, 488 pp.

Haghshenas A. 2004: Protection and conservation of sunn pest tachinid and scelionid parasitoids in Chahar Mahal va Bakhtiari province. In Proceedings of the 16th Iranian Plant Protection Congress, 28 August - 1 September, 2004. Vol. 1. University of Tabriz, Tabriz, Iran, p. 5.

HoNĚK A. 1996: Geographical variation in thermal requirements for insect development. Eur. J. Entomol. 93: 303-312.

HonĚK A. \& KoCOUReK F. 1990: Temperature and development time in insects: a general relationship between thermal constants. Zool. Jb. Syst. 117: 401-439.

Iranipour S. 1996: A Study on Population Fluctuation of the Egg Parasitoids of Eurygaster integriceps Put. (Heteroptera: Scutelleridae) in Karaj, Kamalabad, and Fashand. M.S. Thesis, University of Tehran, Karaj, Iran, 187 pp. [in Persian, English abstr.].

Iranipour S. 2003: Construction and Analysis of Life Tables of Sunn Pest, Eurygaster integriceps Put. (Heteroptera, Scutelleridae) in Varamin Region. Ph.D. Thesis, University of Tehran, Karaj, Iran, 390 pp. [in Persian, English abstr.].

Iranipour S., Kharrazi Pakdel A., Radjabi G., Rasoulian G. \& Karim Modjeni H. 2003: Age specific mortality and temperature dependent development of immature stages of sunn-pest, (Eurygaster integriceps Put.) (Het., Scutelleridae) in four constant temperatures. Appl. Entomol. Phytopath. 70: 1-17 [in Persian, English abstr.].

JAMES D.G. \& WARREN G.N. 1991: Effects of temperature on development, survival, longevity and fecundity of Trissolcus oenone Dodd (Hymenoptera: Scelionidae). J. Aust. Entomol. Soc. 30: 303-306.

Kipyatkov V.E., Lopatina E.B., Imamgaliev A.A. \& Shirokova L.A. 2004: Effect of temperature on rearing of the first brood by the founder females of the ant Lasius niger (Hymenoptera, Formicidae): Latitude-dependent variability of the response norm. J. Evol. Biochem. Phys. 40: 165-175.

KIVAN M. 2008: Development rate and lower temperature threshold in the eggs of Eurygaster integriceps (Heteroptera: Scutelleridae). Insect Sci. 15: 163-166. 
Kivan M. \& KiLIÇ N. 2006a: Age-specific fecundity and life table of Trissolcus semistriatus, an egg parasitoid of the sunn pest Eurygaster integriceps. Entomol. Sci. 9: 39-46.

Kivan M. \& KiLIÇ N. 2006b: A comparison of the development time of Trissolcus rufiventris (Mayr) and Trissolcus simoni Mayr (Hym.: Scelionidae) at three constant temperatures. Turk. J. Agric. For. 30: 383-386.

Kozlov M.A. \& Kononova S.V. 1983: Telenominae of the Fauna of the USSR. Nauka, Leningrad, 336 pp. [in Russian].

Martin H.E., Javahery M. \& Radjabi G. 1969: Note sur la punaise des céréales Eurygaster integriceps Put. et de ses parasites du genre Asolcus en Iran. Entomol. Phytopath. Appl. 28: 38-46 [in Persian, English abstr.].

Nozad B.Z. \& Iranipour S. 2009: Seasonal changes in egg parasitoid fauna of sunn-pest Eurygaster integriceps Puton in wheat fields of new Bonab County, Iran. In Proc. 6th AsiaPacific Congress of Entomology, 18-22 October 2009, Beijing, China. Beijing, pp. 159-160.

Orr D.B., Boethel D.J. \& Jones W.A. 1985: Development and emergence of Telenomus chloropus and Trissolcus basalis (Hymenoptera: Scelionidae) at various temperatures and relative humidities. Ann. Entomol. Soc. Am. 78: 615-619.

Radjabi G. 2000: Ecology of Cereal Sunn Pests in Iran. Agricultural Research, Education, Extension and Organization Press, Tehran, 343 pp. [in Persian].

Radjabi G. 2007: Sunn Pest Management Based on Its Outbreaks: Key Factor Analysis in Iran. Agricultural Research, Education, Extension and Organization Press, Tehran, 163 pp. [in Persian].

Radjabi G. 2008: Insect Ecology, Applied and Considering the Conditions of Iran. 2nd ed. Agricultural Research, Education, Extension and Organization Press, Tehran, 648 pp. [in Persian].

RADJABi G. \& Amir NAZARI M. 1989: Egg parasites of sunn pest in the central part of Iranian plateau. Appl. Entomol. Phytopath. 56: 1-12 [in Persian, English abstr.].

Ratte H. T. 1985: Temperature and insect development. In Hofmann K.H. (ed.): Environmental Physiology and Biochemistry of Insects. Springer, New York, pp. 33-66.

Ruberson J.R., TAuber C.A. \& TAuber M.J. 1995: Developmental effects of host and temperature on Telenomus spp. (Hym.: Scelionidae) parasiting chrysopid eggs. Biol. Control 5: $245-250$.

SAdOYAma Y. 2007: Effects of temperature on the development of Eumicrosoma blissae (Hymenoptera: Scelionidae), an egg parasitoid of the oriental chinch bug, Cavelerius saccharivorus Okajima (Heteroptera: Lygaeidae). Appl. Entomol. Zool. 42: 613-617.

Safavi M. 1973: Etude Bio-Ecologique des Hymenoptères Parasites des Oeufs des Punaises des Cereales en Iran. Ministry of Agriculture and Natural Resources, Tehran, 159 pp. [in Persian].

Salavatiyan M. 1991: The Necessity of Studying Ecological and Biological Effective Factors in Controlling Field Crop Pests. Agricultural Research, Education, Extension and Organization Press, Tehran, 203 pp. [in Persian].

SAS Institute 1999: SAS/STAT User's Guide, Version 7. SAS Institute Inc., Cary, North Carolina, USA.

ShojaI M. 1996: Entomology. Vol. 2. Ontogeny, Biology, Biocoenology. Entomophages. 2nd ed. Tehran University Publications No. 1563, Tehran, pp. 158-195 [in Persian].

Taghaddosi M.V., Kharrazi Pakdel A. \& Esmaili M. 1993: A comparative study on reproductive potential of different populations of Trissolcus grandis Thomson (Hym., Scelionidae), on eggs of sunn pest Eurygaster integriceps Put. (Het., Scutelleridae). In Proceedings of the 11th Iranian Plant Protection Congress, 27 August - 1 September 1993, University of Guilan, Rasht, Iran. p. 7.

Torres J.B., Pratissoli D. \& Zanuncio J.C. 1997: Thermal requirements and development of the egg parasitoids Telenomus podisi Ashmead and Trissolcus brochymenae (Ashmead) on the predator stinkbug Podisus nigrispinus (Dallas). Ann. Entomol. Soc. Braz. 26: 445-453.

Torres J.B., Musolin D.L. \& Zanuncio J.C. 2002: Thermal requirements and parasitism capacity of Trissolcus brochymenae (Ashmead) (Hym: Scelionidae) under constant and fluctuating temperatures, and assessment of development in field conditions. Biol. Sci. Tech. 12: 583-593.

Varley G.C., Gradwell G.R. \& Hassell M.P. 1973: Insect Population Ecology, an Analytical Approach. Blackwell Scientific Publications, Oxford, $212 \mathrm{pp}$.

YEARGAN K.V. 1983: Effects of temperature on developmental rate of Trissolcus euschiti (Hymenoptera: Scelionidae), a parasite of stink bug eggs. Ann. Entomol. Soc. Am. 76: $757-760$.

Zomorrodi A. 1961: A progress in biological control of sunnpest. Entomol. Phytopath. Appl. 20: 16-23 [in Persian, English abstr.].

Received September 24, 2009; revised and accepted November 18, 2009 